\title{
THE ASSESSMENT OF CORPORATE TRAINING AND THE EVALUATION OF SELECTED WORK ATTRIBUTES
}

\author{
Zuzana Birknerová, ${ }^{1}$ Miroslav Frankovský, ${ }^{2}$ Eva Benková ${ }^{3}$
}

\begin{abstract}
The contemporary economic environment including the context of work is characterized by unusual turbulence and an unflagging stream of changes. The effective operation of organizations in these conditions is more and more conditioned by the quality of human resources. Corporate training represents one of the significant factors of increasing this quality. In this paper, we present the results of our research which specifies connections between the assessment of corporate training and the evaluation of selected work attributes. Based on the data which were obtained by the original SBES methodology, it is obvious that there are significant connections between the perception of corporate training factors and the evaluation of work attributes. The most evident were the connections between the assessment of the corporate training factor 'Significance for performing a profession' and the attributes of 'Interesting work, Delight from work and Possibility of being promoted at work.'
\end{abstract}

JEL Classification Numbers: I250; DOI: http://dx.doi.org/10.12955/cbup.v5.898

UDC Classification: 376

Keywords: corporate training, work, work attributes, work effectiveness, SBES methodology

\section{Introduction}

Nowadays, the educational level of employees belongs to the basic aims and priorities of each organization. At the same time, it is a requirement and a necessity so that an individual can be successful in the contemporary labor market, and be able to perform the working duties and vice versa, so that the organization could their growth, continuous improvement, and development of their educational level. Fitzgerald (1992) defines corporate training as a tool which helps an individual to support the organization and to succeed at their current position as well as the acquisition of knowledge and skills which are related to the existing tasks.

The essence of corporate training is the effort to improve knowledge, attitudes, and skills of employees. Corporate training can also increase the employees' trust, their motivation and subjective satisfaction with their job (Fill and Mullins, 1990). Milkovich and Boudreau (1991) define this training as a systematic process of the change of employees' behavior, knowledge, and motivation with the aim to increase the level of agreement between the employee's features and the requirements put on them.

Modern and contemporary organizations relate their success and competitiveness to the preparation and creation of employees' working potential so that they could reach a high level of talent, skills, knowledge, and motivation. They are searching for capable, professionally, and psychologically prepared job applicants or they ensure a professional preparation for their employees. Corporate training is a significant technique leading to the productivity increase (Goldstein and Goldstein, 1990).

An employee's corporate training is carried out as a direct result of the requirement of their superior. We can find out educational needs by the means of the so called "analysis of educational needs." According to Milkovich and Boudreau (1991), the given analysis is carried out at several levels. According to Srivastava (2002), training follows continuous innovation by creating the connection between the external and internal organization world which helps the organization to keep its competitiveness.

The organization survival depends on its ability to equip its employees with the right skills and competences completed with the right attitudes. In this way, they serve the aims of the organization, especially by the means of increasing the adaptability and ability to react to the changes in the economic and business environment.

Gould et al. (2004) state that the analysis of educational needs is a first step in the strategy of organizational training and it is crucial to satisfy the needs of the employee's permanent professional development. The analysis of educational needs must be therefore carefully planned, managed, and

\footnotetext{
${ }^{1}$ The Faculty of Management,Slovakia, zuzana.birknerova@unipo.sk

${ }^{2}$ The Faculty of Management, Slovakia, miroslav.frankovsky@unipo.sk

${ }^{3}$ The Faculty of Management, Slovakia, eva.benkova@unipo.sk
} 
directed towards clear results so that the educational actions are ensured to be applied effectively and they could lead to meaningful changes, e.g. in the quality of services provided by the organization.

An inevitable part of the concept of corporate training is an evaluating analysis which is carried out continuously. Hamblin (1974) understands the evaluation of corporate training in the context of information (feedback) about the effects of a training programme and the evaluation of the training in the light of this information. Evaluation should give a comprehensive reply to a question whether training fulfilled its purpose from the point of view of acquiring new skills and knowledge but also from the point of view of subjective perception of work attributes. The position of corporate training is determined by the fact that training is a tool not a goal. To be effective, corporate training has to respect the organization requirements as well as the employees' possibility (Sadler-Smith, 2006). The mentioned attributes of corporate training are reflected in the concepts of this issue of several authors (Spector, 1997; Russ-Eft, 2008; Fitzgerald, 1992 a i.).

\section{Research}

The research sample was created by the employees of a private and public sphere operating in the sector of production, administration, and a school system. We addressed 152 respondents, from which 87 were men $(57,20 \%)$ and 65 women $(42,80 \%)$, in the age from 21 to 62 years (the average age was 40,84 years, standard deviation was 10,510). The employees had an average length of practice of 17,36 years (standard deviation was 10,806 years). The minimum length of practice was 1 year and maximum length 44 years. From the total number of employees, 92 operate in a private sphere $(60,50 \%)$ and 60 in a public sphere $(39,50 \%)$. We addressed 51 employees working in the sector of economic production (33,60\%), 36 in administration $(23,70 \%)$ and 21 in a school system $(13,80 \%)$.

The data in a presented research were acquired by the means of SBES methodology (Frankovský et al., 2015; Birknerová et al., 2016a, 2016b). The methodology contains 22 items, based on which the respondents were assessing different aspects of corporate training. The individual items were evaluated on a 5-point scale, where $1=$ certainly no, $2=$ rather no, $3=$ neither no, nor yes, $4=$ rather yes, $5=$ certainly yes. Corporate training was assessed by the means of factors which explain $65,6 \%$ variances.

The Principal Component Analysis with Varimax Rotation was used to extract 4 factors the content of which may be described as follows:

- F1: Significance for the profession. Respondents scoring high in this factor attach greater importance to education for the profession; they perceive a greater personal significance of education and see a higher degree of relation to the work performance (Cronbachova alpha $0,899)$.

- F2: Benefits for the employees. Respondents with higher scores in this factor attach greater importance to education for career development, positive evaluation, improvement of relationships on the workplace, and for motivation increase (Cronbachova alpha-0,844).

- F3: Expectations of the employees. Respondents scoring high in this factor provide positive evaluation of the education program, utilized methods and forms of education and the training course, and have also higher expectations (Cronbachova alpha-0,860).

- F4: Satisfaction of the employees. Respondents with higher scores in this factor evaluate education as more comprehensible, acceptable, and adequate time-wise (Cronbachova alpha $0,771)$.

Selected work attributes were evaluated from the point of view whether they contribute or not to the achievement of good results at work. The respondents had a possibility to assess the following work attributes: interesting job, delight from the results at work, thrilling situations, free working time, wage, the possibility to be promoted, competition among co-workers, social usefulness of the work, appreciation from co-workers, and appreciation from a superior. Individual attributes were assessed at a nominal bipolar range yes - no.

The differences in assessing corporate training from the point of view of evaluating selected work attributes were analysed by the means of a mathematic-statistical method of t-test for two independent selections in the statistical program SPSS 20 . The results of the analysis are presented in Tables $1-4$. The tables show only those attributes by which statistically significant differences were found out. 


\begin{tabular}{|c|c|c|c|c|}
\hline \multirow{5}{*}{ Interesting work } & \multicolumn{4}{|c|}{ F1 - Significance for performing the profession } \\
\hline & Average - yes & $\begin{array}{c}\text { Standard deviation } \\
- \text { yes }\end{array}$ & \multirow[t]{2}{*}{$\mathrm{T}$-test } & \multirow[t]{2}{*}{ Significance } \\
\hline & Average - no & $\begin{array}{c}\text { Standard deviation } \\
- \text { no }\end{array}$ & & \\
\hline & 3.80 & 1.03 & \multirow[t]{2}{*}{-5.610} & \multirow[t]{2}{*}{0.000} \\
\hline & 2.90 & 0.93 & & \\
\hline & \multicolumn{4}{|c|}{ F1 - Significance for performing the profession } \\
\hline \multirow{4}{*}{ Delight from work } & Average - yes & $\begin{array}{c}\text { Standard deviation } \\
- \text { yes }\end{array}$ & \multirow[t]{2}{*}{$\mathrm{T}$-test } & \multirow[t]{2}{*}{ Significance } \\
\hline & Average - no & $\begin{array}{c}\text { Standard deviation } \\
- \text { no }\end{array}$ & & \\
\hline & 4.01 & 0.90 & \multirow[t]{2}{*}{-6.146} & \multirow[t]{2}{*}{0.000} \\
\hline & 2.99 & 0.99 & & \\
\hline & \multicolumn{4}{|c|}{ F1 - Significance for performing the profession } \\
\hline \multirow{4}{*}{$\begin{array}{l}\text { Possibility of being } \\
\text { promoted at work }\end{array}$} & Average - yes & $\begin{array}{c}\text { Standard deviation } \\
- \text { yes }\end{array}$ & \multirow[t]{2}{*}{$\mathrm{T}$-test } & \multirow[t]{2}{*}{ Significance } \\
\hline & Average - no & $\begin{array}{c}\text { Standard deviation } \\
- \text { no }\end{array}$ & & \\
\hline & 4.14 & 0.86 & \multirow[t]{2}{*}{-3.575} & \multirow[t]{2}{*}{0.000} \\
\hline & 3.22 & 1.05 & & \\
\hline
\end{tabular}

The results of the mathematical-statistical analysis proved the existence of significant differences in assessing the corporate training factor of the Significance for performing a profession between the respondents who agreed that work attributes Interesting work. Delight from work and the Possibility to be promoted at work contribute to reach good results at work and the respondents who did not agree that Interesting work. Delight from work and the Possibility to be promoted at work contribute to reach good results at work. It proves the fact that the respondents who assessed the mentioned corporate training factor more positively also agreed that interesting work. delight from work and the possibility to be promoted significantly influence the achievement of good results at work (Table 1)

The acquired results from the analysis in assessing the corporate training factors of the Advantages for employees and the Expectations of employees proved similar findings. But the significant differences between the respondents who agreed or did not agree with the influence of work attribute on work results only proved from the point of view of the attributes of Delight from work and the Possibility to be promoted at work (table 2 and table 3). Also in this case. the respondents who assessed the mentioned corporate training factors more positively agreed that the delight from work and the possibility to be promoted at work influence the achievement of good results at work.

\begin{tabular}{|c|c|c|c|c|}
\hline \multirow{5}{*}{ Delight from work } & \multicolumn{2}{|c|}{ F2 - Benefits for the employees } & \multirow{3}{*}{$\mathrm{T}$-test } & \multirow{3}{*}{ Significance } \\
\hline & Average - yes & $\begin{array}{c}\text { Standard deviation } \\
- \text { yes }\end{array}$ & & \\
\hline & Average - no & $\begin{array}{c}\text { Standard deviation } \\
- \text { no }\end{array}$ & & \\
\hline & 3.24 & 1.05 & \multirow[t]{2}{*}{2.581} & \multirow[t]{2}{*}{0.011} \\
\hline & 2.82 & 0.90 & & \\
\hline & \multicolumn{4}{|c|}{ F2 - Benefits for the employees } \\
\hline \multirow{4}{*}{$\begin{array}{l}\text { Possibility of being } \\
\text { promoted at work }\end{array}$} & Average - yes & $\begin{array}{c}\text { Standard deviation } \\
- \text { yes }\end{array}$ & \multirow[t]{2}{*}{$\mathrm{T}$-test } & \multirow[t]{2}{*}{ Significance } \\
\hline & Average - no & $\begin{array}{l}\text { Standard deviation } \\
\text { - no }\end{array}$ & & \\
\hline & 3.45 & 1.24 & \multirow[t]{2}{*}{2.327} & \multirow[t]{2}{*}{0.021} \\
\hline & 2.90 & 0.91 & & \\
\hline
\end{tabular}




\begin{tabular}{|c|c|c|c|c|}
\hline \multirow{5}{*}{ Delight from work } & \multicolumn{4}{|c|}{ F3 - Expectations of the employees } \\
\hline & Average - yes & $\begin{array}{c}\text { Standard deviation } \\
\text { - yes }\end{array}$ & \multirow[t]{2}{*}{$\mathrm{T}$-test } & \multirow[t]{2}{*}{ Significance } \\
\hline & Average - no & $\begin{array}{c}\text { Standard deviation } \\
\text { - no }\end{array}$ & & \\
\hline & 3.21 & 1.18 & \multirow[t]{2}{*}{2.929} & \multirow[t]{2}{*}{0.004} \\
\hline & 2.73 & 0.81 & & \\
\hline & \multicolumn{4}{|c|}{ F3 - Expectations of the employees } \\
\hline \multirow{4}{*}{$\begin{array}{l}\text { Possibility of being } \\
\text { promoted at work }\end{array}$} & Average - yes & $\begin{array}{c}\text { Standard deviation } \\
\text { - yes }\end{array}$ & \multirow[t]{2}{*}{$\mathrm{T}$-test } & \multirow[t]{2}{*}{ Significance } \\
\hline & Average - no & $\begin{array}{c}\text { Standard deviation } \\
- \text { no }\end{array}$ & & \\
\hline & 3.42 & 0.91 & \multirow[t]{2}{*}{2.499} & \multirow[t]{2}{*}{0.014} \\
\hline & 2.81 & 1.25 & & \\
\hline
\end{tabular}

The analysis of the differences in assessing the corporate training factor of Employees' Satisfaction proved the significant differences between the respondents in the examined context from the point of view of work attributes of Interesting work and Delight from work. As already mentioned. the respondents who assessed the corporate training factor of Employees' satisfaction agreed that the delight from work and interested work influence the achievement of good results at work (table 4).

\begin{tabular}{|c|c|c|c|c|}
\hline & & F4-Satisfactio & employ & \multirow{3}{*}{ Significance } \\
\hline \multirow{4}{*}{ Interesting work } & Average - yes & $\begin{array}{c}\text { Standard deviation } \\
\text { - yes }\end{array}$ & \multirow[t]{2}{*}{$\mathrm{T}$-test } & \\
\hline & Average - no & $\begin{array}{c}\text { Standard deviation } \\
\text { - no }\end{array}$ & & \\
\hline & 3.29 & 0.92 & \multirow[t]{2}{*}{-2.026} & \multirow[t]{2}{*}{0.045} \\
\hline & 2.99 & 0.89 & & \\
\hline & \multicolumn{4}{|c|}{ F4 - Satisfaction of the employees } \\
\hline \multirow[t]{4}{*}{ Delight from work } & Average - yes & $\begin{array}{c}\text { Standard deviation } \\
\text { - yes }\end{array}$ & \multirow[t]{2}{*}{$\mathrm{T}$-test } & \multirow[t]{2}{*}{ Significance } \\
\hline & Average- no & $\begin{array}{c}\text { Standard deviation } \\
\text { - no }\end{array}$ & & \\
\hline & 3.41 & 0.90 & \multirow[t]{2}{*}{-2.718} & \multirow[t]{2}{*}{0.007} \\
\hline & 2.99 & 0.89 & & \\
\hline
\end{tabular}

\section{Discussion and conclusion}

If an organization wants to make a progress. it is inevitable to pay attention to the corporate training of employees; the character. the level and the intensity of which can be different according to the needs of the organization (Sadler-Smith. 2006) and the employees' possibilities. One of the important aspects of the corporate training effectiveness is the perception and evaluation of this training by the employees (Lelková and Lorincová. 2017; Vávrová et al. 2012) and thus also a question of getting a feedback (Rajnoha et al. 2016) and other work aspects (Štefko and Gallo. 2015). A crucial factor of the development of any organization are its employees. a human capital. The performance and the competitiveness of an organization is from the point of view of its employees conditioned by the development of their competences and self-management (Russ-Eft. 2008). ) In this context. the attention is focused not only on the evaluation and remuneration. but also on a development and training. The development of employees puts an organization into a position when they can directly not only face changes. react to changes but also to suggest. to create a change (Fitzgerald. 1992). In connection to understanding the economic environment as turbulent with a never-ending flow of changes (Drucker. 1999). the attention paid to the development of human capital is inevitable. 
The presented results prove the meaningfulness of thinking about the significance of corporate training also from the point of view of assessing the work by employees. The identified and specified connections between assessing the corporate training attributes (significance. advantages. expectations and satisfaction) and perception of the work (delight from work. interesting work. the possibility to be promoted) prove the mentioned thinking. (Fill and Mullins. 1990). The employees who assessed the individual corporate training attributes more positively agreed also with the mentioned work attributes as significant prerequisites for good results at work. In the context of corporate training. these findings focus the attention not only on the aspects of the development of findings. knowledge. and skills. but also on a possible influence of this training on a psychic aspect. experiencing one's own work. Such an approach enables a more complex view on the position of corporate training also from the point of view of motivation. loyalty and other work attributes which are connected to a subjective work picture. The research results proved the findings which are connected to specifying the external and internal motivation factors of education. These findings correspond with the findings which are presented by Buckley and Caple (2007). From a methodological point of view. the presented results prove the legitimacy of a structural approach (significance. advantages. expectations and satisfaction) to discovering a feedback assessment of corporate training. At the same time. it is possible to consider the results of this study as a contribution to verifying the use of the SBES methodology (Frankovský et al. 2015; Birknerová et al. 2016a. 2016b).

\section{Acknowledgement}

The contribution is the result of KEGA Project 003PU-4/2017.

\section{References}

Birknerová. Z.. Frankovský. M.. Zahatňanská. M.. Daňková. Z. (2016b). Assessment of Corporate Training by Employees. In World Congress on Education (WCE-2016). Published by Infonomics Society. 36-39.

Birknerová. Z.. Frankovský. M.. Zahatňanská. M.. Zbihlejová. L. (2016a.) Differences in evaluation of corporate training from the viewpoint of the work position and sector. International journal for infonomics. Vol. 9. no. 1. 1131-1138.

Buckley. R.. Caple. J.(2007). The Theory and Practice of Training (5th ed.). Kogan Page. London.

Drucker. P. F. (1999). Management challenges for the 21st century. New York: Harper-Collins. 207.

Fill. C.. Mullins. L.(1990). The effective management of training. In Industrial and commercial training. 22. 1990. 1. 13-16.

Fitzgerald. W. (1992). Training Versus Development. In Training \&Development. 46. 1992. 5. 81-83.

Frankovský. M.. Birknerová. Z.. Štefko. R.. Zbihlejová. L.. Zahatňanská. M. (2015). Possibilities of Determining the Effectiveness of Corporate Training. World Congress on Education. WCE 2015: World congress on education. 19-21. Dublin. Ireland: Infonomic society. 58-62.

Goldstein. I. L..Goldstein. H.W.(1990). Training as an Approach for Organisations to the Challenges of Human Resource Issues in the Year 2000. In Journal of Organizational Change Management. 3. 1990. 2. 30-44.

Gould. D.. Kelly. D.. White.. I. (2004). Training needs analysis: an evaluation framework. In Nursing Standard. 18. 2004. 20. 33-37.

Hamblin. A. C. (1974). Evaluation and Control of Training. McGraw-Hill European series in management. 208.

Lelková. A.. Lorincová. T. (2017). Prediction of manipulation as a core part of social intelligence through selected personality traits in the context of business area. In International Journal of Organizational Leadership. 6 (1). 102-108.

Milkovich. G.T.. Boudreau. J.W. (1991). Human Resource Management. Published by Richard D Irwin. 1991.

Rajnoha. R.. Štefko. R.. Merková. M.. Dobrovič. J. (2016). Business intelligence as a key information and knowledge tool for strategic business performance management. In Economics and management. 19 (1). 183-202.

Russ-eft. D.F. (2008). Evaluator competencies: Standards for the practice of evaluation in organizations. Jossey-Bass. San Francisco. 2008.

Sadler-Smith. E. (2006). Learning and Development for Managers: Perspectives from Research and Practice. WileyBlackwell. 488.

Spector. P.E. (1997). Advanced Topics in Organization Behavior: Job satisfaction: Application. assessment. causes. and consequences. SAGE Publications. Thousand Oaks. CA. 1997.

Srivastava. M. P. (2002). Human Resources Training Paradigms: Need for Change. New Delhi: Manak Pub. In Journal of Services Research. 2. 2002.. 1.. 189-192.

Štefko. R.. Gallo. P. 2015. Using Management Tools to Manage Network Organizations and Network Models. In Sroka W.. Hittmár Š. (Eds.). Management of Network Organizations. Theoretical Problems and the Dilemmas in Practice. Springer International Publishing Switzerland. 249-265.

Vávrová. S.. Hladík. J.. Hrbčáková. K. (2012). The Determinants of Self-Regulated Learning Development in Students of Helping Professions. Procedia - Social and Behavioral Sciences. 2012. Vol. 69. 332-340. 